\section{Population and roosting behaviour of Barn Swallows Hirundo rustica wintering in Jamshedpur, Jharkhand, India}

\section{Sushant Kumar Verma}

At \& P.O. - Harharguttu, Near TRF Colony, Jamshedpur, Jharkhand 831002, India

Email: vermasushant2008@gmail.com

The Barn Swallow Hirundo rustica is the most widespread species of swallows in the world (Turner et al. 1989). It breeds from the central and eastern Himalaya to Japan and Korea and winters across tropical Asia from India and Sri Lanka east to Indonesia and New Guinea (Turner et al. 1989). Its preferred habitat during breeding season is open country with low vegetation. Sinclair et al. (2002) found that they become cosmopolitan during winter avoiding dense forests and deserts. Winter roost-sites are typically in reed-beds close to rivers and lakes (Curry-Lindahl 1963; Nutall 2000). In addition to reed-beds, maize or sugarcane fields are also used for roosting (Cramp 1988). Medway (1973) found that in western Malaysia Barn Swallows roosted extensively not only in Phragmites beds, but also on overhead wires in 26 towns. Similar observations were made by George (1965) in Mumbai (India), where he found that besides using sugarcane plantations and mangrove swamps as their traditional roosting place, thousands of Barn Swallows also roosted on overhead wires in certain crowded parts near the city. In Honshu, the Barn Swallow is more an urban bird, with the Red-rumped Swallow Cecropis daurica replacing it in rural landscape (Turner et al. 1989). Their gregarious roosting behaviour helps to reduce predation risk (Bijlsma \& van den Brink 2005) and to conserve energy (Rudebeck 1955).

The Barn Swallow Hirundo rustica is a non-breeding winter visitor to Jamshedpur, Jharkhand (India). There is lack of information about the roosting behaviour of Barn Swallows wintering in Jamshedpur, hence the present study.

Date of publication (online): 26 February 2010

Date of publication (print): 26 February 2010

ISSN $0974-7907$ (online) | 0974-7893 (print)

Editor: Rajah Jayapal

Manuscript details:

Ms \# 02161

Received 18 March 2009

Final received 24 September 2009

Finally accepted 09 February 2010

Citation: Verma, S.K. (2010). Population and roosting behaviour of Barn Swallows Hirundo rustica wintering in Jamshedpur, Jharkhand, India. Journal of Threatened Taxa 2(2): 721-723.

Copyright: @ Sushant Kumar Verma 2010. Creative Commons Attribution 3.0 Unported License. JoTT allows unrestricted use of this article in any medium for non-profit purposes, reproduction and distribution by providing adequate credit to the authors and the source of publication.

Acknowledgements: The author is thankful to Dr. A. Alim, Department of Zoology, Jamshedpur Co-operative College, Jamshedpur, for valuable suggestions. The author expresses his sincere gratitude to Miss Ghazala Sabih and Mr. Abhishek Raj for generous help, encouragement and inspiration.

OPEN ACGESS | FREE DOWNLOAD

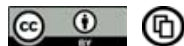

\section{Methods}

The roosting pattern of Barn Swallows was studied from September 2006 to April 2008. This study was carried out on a major communal roosting area in Jamshedpur, India (22046'20.12"N \& $86^{\circ} 11^{\prime} 32.66$ 'E) in a commercial area adjacent to Tatanagar Railway Station. The approximate population of $\mathrm{H}$. rustica during the entire roosting period was determined by random counting. For random counting, the average number of Barn Swallows settled on $1 \mathrm{~m}$ wire was determined which was then multiplied by the total length of wire. Ten such samplings were done on every fifteenth day of each month throughout the study period.

Roost was watched for five days in each month to record presence and activities of predatory birds. Monitoring was done for four hours after the birds settled on wires.

Mean roosting time (relative to sunset) for each month was calculated to trace out any fluctuation in relation to available time period between sunset and the end of twilight. Sunset time is defined here as the time when the upper arc of the sun was on the true horizon.

\section{Results}

First appearance of Barn Swallows was noted in early September in both years of the study. Seasonal increase in number was observed from September to a peak in December (Fig. 1). Departure of birds starts from late March and continues to middle of April. Roosting time relative to sunset was significantly late in February and March. A correlation exists between roosting time and cloud cover. Birds roosted early in the evening (around 13 to 17 minutes after sunset) when the weather was cloudy. Almost in all evenings when the sky was clear birds roosted much late (24 to 28 minutes after sunset). Mean time of roosting in minutes after sunset for each month is given in Table 1. Time interval between roosting of the early and last bird usually spanned 10 to 17 minutes. It was noted that 10 to 12 roosting swallows occupied $1 \mathrm{~m}$ of electricity wire (Image 1). Such occurrence was more or less uniform across the entire roost colony which enabled me to extrapolate total population from random samples. A uniform spacing of about $8 \mathrm{~cm}$ was noted between two individual roosting swallows (Image 2). No patterns could be observed in the direction of facing of birds during roosting. On seeing any predator like Barn Owl or cat, large numbers would fly off and settle at the same place after a while.

\section{Discussion and Conclusion}

The non-breeding winter visitor Hirundo rustica exhibits gregarious, communal roost outside the breeding season in Jamshedpur, Jharkhand (India). The site of roosting remained highly illuminated with artificial lights throughout the night. Possible reasons for selection of such sites for roosting by Barn Swallows may be: (a) presence of artificial lighting to ward off predatory birds, especially owls (b) higher thermal gradients in urban agglomerates for generating warmth, and (c) availability of insects attracted towards artificial lights being substantial food source. However, availability of food insects appears to be a low priority factor for urban roosting of $H$. rustica. A concomitant increase in the number of predatory birds indicates the risk of predation. As communal roosting benefits individuals as a means of reducing predation risk due to improved vigilance for predators (Pulliam \& Caraco 1984; Bijlsma \& van den Brink 2005), H. rustica also resorts to 


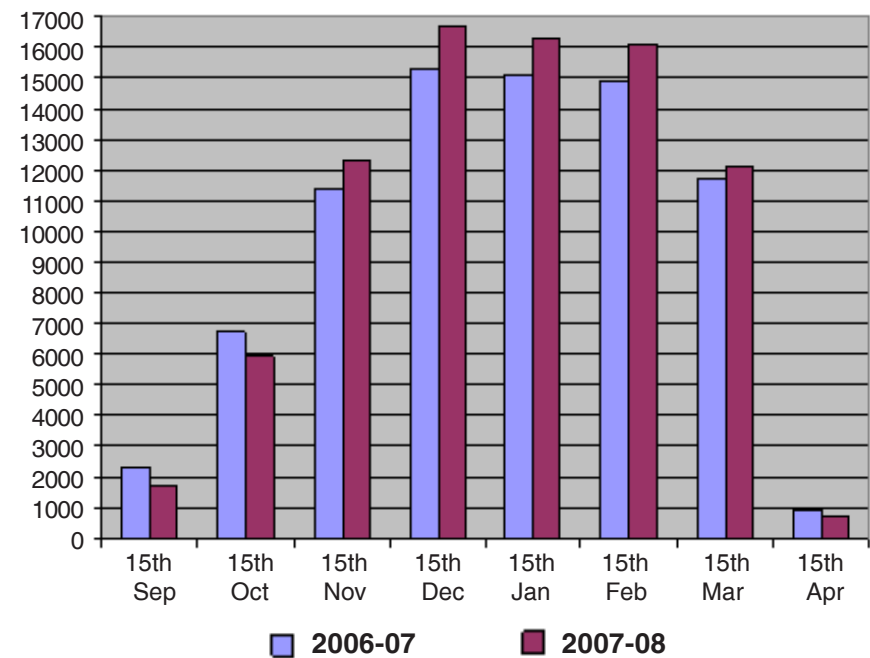

Figure 1. Monthly population of Barn Swallows during study period

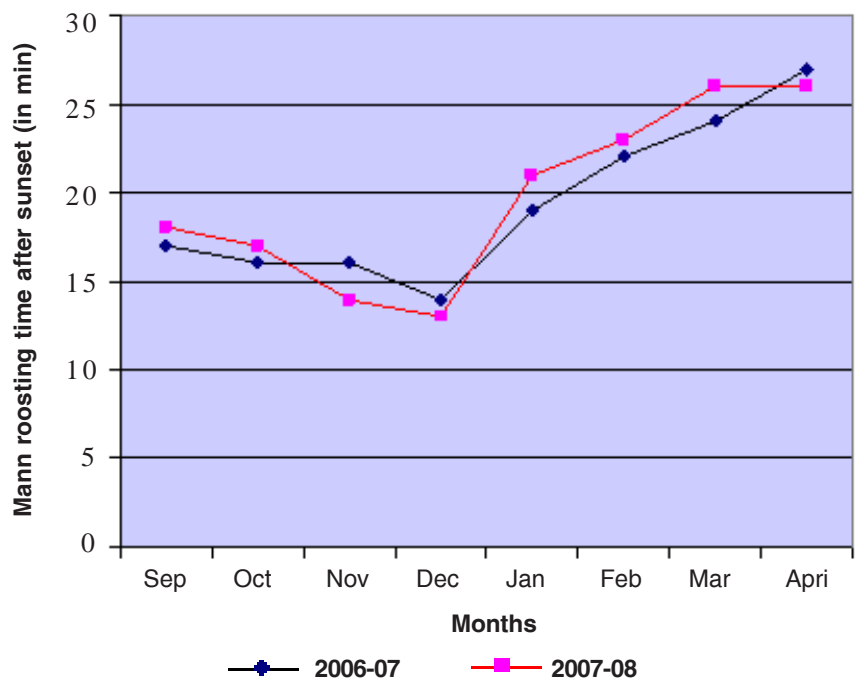

Figure 2. Graph illustrating month-wise roosting time after sunset (in min.) of $H$. rustica

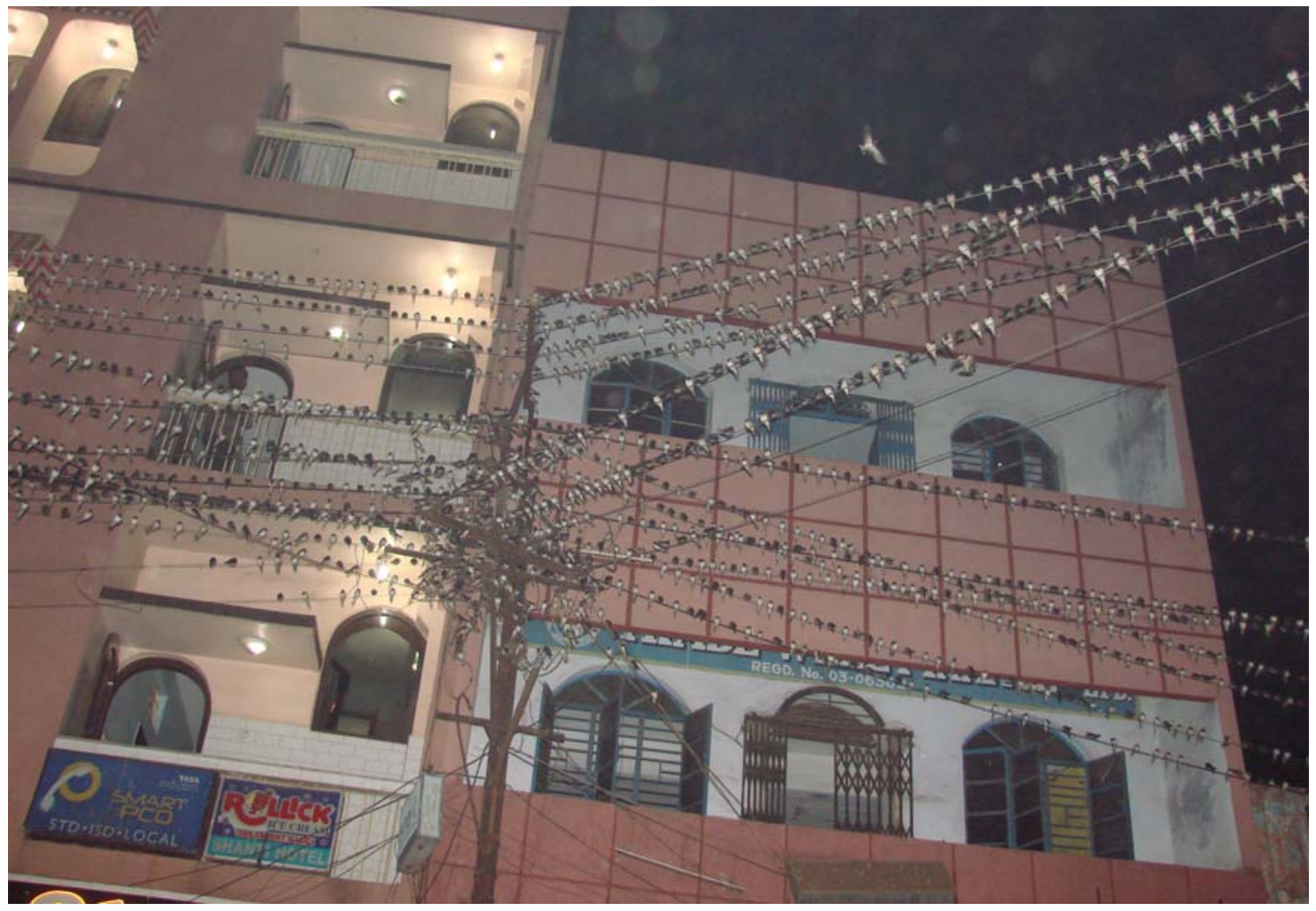

Image 1. Hirundo rustica roosting gregariously in overhead wires at commercial part of the town Jamshedpur. 
Table 1. Mean and \pm SD of month-wise roosting time after sunset (in $\mathrm{min}$ ) of $\boldsymbol{H}$. rustica

\begin{tabular}{lcc}
\hline Month & $\begin{array}{c}\text { Mean roosting time after sunset (in minutes) } \\
\mathbf{2 0 0 6 - 2 0 0 7}\end{array}$ & $\mathbf{2 0 0 7 - 2 0 0 8}$ \\
\hline September & $17 \pm 0.86$ & $18 \pm 1.43$ \\
October & $16 \pm 1.32$ & $17 \pm 1.24$ \\
November & $16 \pm 1.22$ & $14 \pm 1.10$ \\
December & $14 \pm 1.03$ & $13 \pm 0.84$ \\
January & $19 \pm 1.09$ & $21 \pm 0.65$ \\
February & $22 \pm 0.72$ & $23 \pm 0.88$ \\
March & $24 \pm 0.98$ & $28 \pm 1.03$ \\
April & $27 \pm 1.01$ & $26 \pm 1.21$ \\
\hline
\end{tabular}

communal roosting.

It was observed that Barn Swallows roosted significantly later (relative to sunset) in February-April than in SeptemberJanuary. Giller (1955) reported that roosting time of $H$. rustica may be influenced by rain and low temperature. Similar observations were made by Loske (1984). Early roosting in cloudy weather and during the months of February-April and late roosting in clear weather and during the months of September-January proves that availability of light is an important factor.

\section{References}

Bijlsma, R.G. \& B. van den Brink (2005). A Barn Swallow Hirundo rustica roost under attack: timing and risks in the presence of African Hobbies Falco cuvieri. Ardea 93: 37-48.

Cramp, S. (1988). The Birds of The Western Palearctic, 5. Oxford: Oxford University Press.

Curry-Lindahl, K. (1963). Roosts of Swallows (Hirundo rustica) and House Martins (Delichon urbica) during the migration in Tropical Africa. Ostrich 34: 99-101

George, P.V. (1965). Swallows Hirundo rustica Linnaeus roosting on wires. Journal of the Bombay Natural History Society 62: 160.

Giller, F. (1955) Beobachtungen an einem Rauchschwalbenschlafplatz. Vogelwelt 76: 180-184.

Loske, K.H. (1984). Beobachtungen an mittelwestfälischen Schlafplätzen der Rauchschwalbe (Hirundo rustica). Vogelwelt

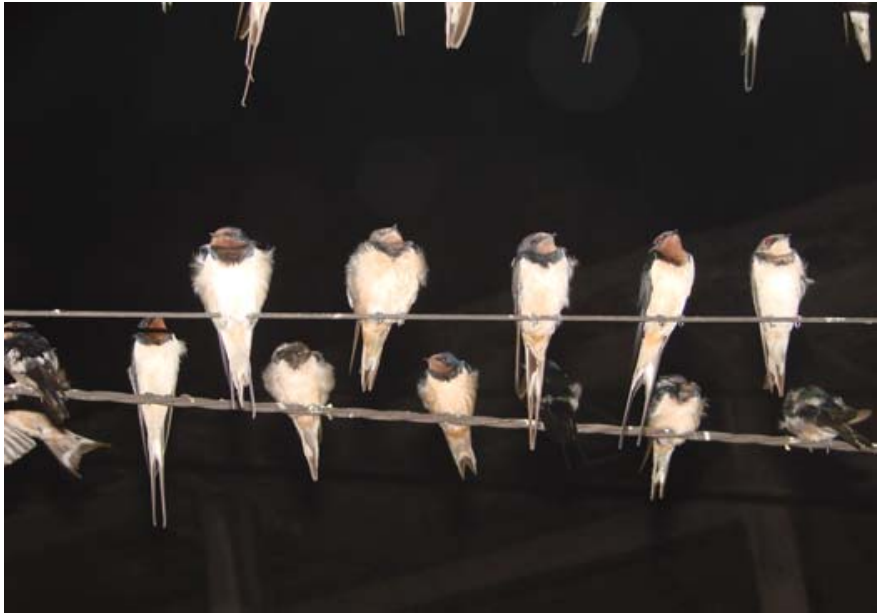

Image 2. Roosting pattern of Barn Swallow Hirundo rustica. Pictures taken at the Station Road, Jugslai, Jamshedpur.

105: 51-60.

Medway, L. (1973). A ringing study of migratory Barn Swallows in west Malaysia. Ibis 115: 60-86.

Nuttall, R.J. (2000). European swallow roosts in the Memel District, Free State, South Africa. Mirafra 17: 57-58.

Pulliam, H.R. \& T. Caraco (1984). Living in groups: Is there an optimal size? Behavioural Ecology: An Evolutionary Perspective. Blackwell, Oxford, 122-147pp.

Rudebeck, G. (1955). Some observations at a roost of European Swallows and other birds in the south-eastern Transvaal. Ibis 97: 572-580.

Sinclair, I., P. Hockey \& T. Warwick (2002). SASOL Birds of Southern Africa. Cape Town: Struik, 294pp.

Turner, A.K \& C. Rose (1989). Swallows \& Martins: An Identification Guide and Handbook. Boston: Houghton Mifflin, 164-169pp.

Van den Brink, B., R.G Bijlsma \& T.M. van der Have (1998). European songbirds and Barn Swallows Hirundo rustica in Ghana: a quest for Constant Effort Sites and swallow roosts in December/ January 1996/97. WIWO report 58: 1-55. 